\title{
PERLAKUAN AKUNTANSI ASET TETAP PADA PERUSAHAAN DAERAH AIR MINUM KABUPATEN KUDUS
}

\author{
Tentyadesty Enggar Panggalih, Didiek Susilo Tamtomo \\ Jurusan Akuntansi/Program Studi Akuntansi \\ Jalan Prof. H. Sudarto, S.H. Tembalang, Semarang 50275
}

\begin{abstract}
Abstrak: Tugas Akhir ini bertujuan untuk Menghitung dan mengakui aset tetap, mencatat aset tetap serta menyajikan dan mengungkapkan aset tetap Perusahaan Daerah Air Minum Kabupaten Kudus. Metode penulisan yang digunakan yaitu metode deskripsi dan eksposisi . Metode deskripsi digunakan untuk mendeskripsikan gambaran umum Perusahaan Daerah Air Minum Kabupaten Kudus dan metode eksposisi digunakan untuk menjelaskan perlakuan aset tetap pada Perusahaan Daerah Air Minum Kabupaten Kudus. Hasil dari penulisan Tugas Akhir ini yaitu aset tetap diakui pada saat aset tetap siap digunakan sebesar harga perolehan. Perhitungan harga perolehan aset tetap sampai dengan 31 Desember 2016 sebesar Rp 126.734.497.850, akumulasi aset tetap sampai dengan 31 Desember 2016 sebesar $R p$ 49.116.678.669, dan beban penyusutan sampai dengan 31 Desember 2016, pencatatan aset tetap ke dalam jurnal, buku besar dan buku pembantu, serta penyajian dan pengungkapan aset tetap pada Laporan Keuangan.
\end{abstract}

Kata Kunci : Daftar Aset Tetap, Pengakuan Aset Tetap, Pencatatan Aset Tetap, Pengungkapan Aset Tetap

\begin{abstract}
The goals of final report are to calculate and recognize fixed assets, record fixed assets and present, disclose the fixed assets of Kudus Disctrict water company. The method of writing used in this final report is description method and exposition methode. The description method is used to describe the general description of Kudus Disctrict water company and the exposition is used to explain the treatment of fixed assets at Kudus Disctrict water company. The result of this Final report is Fixed assets are recognized when the asset is ready for use at acquisition cost. Calculation of the acquisition price of fixed assets until December 31, 2016 amounting to $R p$ 126,734,497,850, the accumulated fixed assets up to December 31, 2016 amounting to $R p$ 49,116,678,669, and depreciation expense up to December 31, 2016, the recording of fixed assets In journal, ledger and subsidiaries ledger, and the presentation and disclosure of property and equipment to the Financial Statements.
\end{abstract}

Keywords : List of Fixed Assets, Fixed Asset Recognition, Fixed Assets Record, Fixed Assets Disclosure

\section{PENDAHULUAN \\ Latar Belakang Masalah}

Perusahaan Daerah Air Minum

(PDAM) Kabupaten Kudus adalah perusahaan air minum yang didirikan berdasarkan Peraturan Daerah (PERDA) Kabupaten Kudus No.31 Tahun 1990 tanggal 23 Oktober 1990 yang sekarang diubah menjadi Peraturan Daerah Kabupaten Kudus No.9 Tahun 2005. Tujuan PDAM Kabupaten Kudus yaitu pertama menyediakan air minum yang memenuhi syarat kesehatan bagi masyarakat dengan pelayanan prima yang berorientasi lingkungan. Kedua turut menunjang program pemerintah di bidang pembangunan daerah, pembangunan ekonomi daerah dan pendapatan asli daerah. Lapangan usaha PDAM Kabupaten Kudus adalah mengusahakan penyediaan air minum yang memenuhi syarat-syarat kesehatan 
bagi masyarakat dan mengembangkan jenis usaha lain yang menyangkut pengelolaan air dalam rangka menunjang pembanguna ekonomi daerah Kabupaten Kudus. Transaksi yang terdapat pada PDAM Kabupaten Kudus diolah dan disajikan dalam bentuk Laporan Keuangan PDAM Kabupaten Kudus yang terdiri dari Laporan Posisi Keuangan, Laporan Laba-Rugi, Laporan Perubahan Ekuitas, dan Catatan atas Laporang Keuangan. Salah satu Komponen Laporan Posisi Keuangan yaitu aset tetap yang digunakan untuk menunjang kegiatan operasional di PDAM Kabupaten Kudus.

Aset tetap menurut Ikatan Akuntan Indonesia dalam PSAK No 16 Aset tetap adalah aset berwujud yang dimiliki untuk digunakan dalam produksi atau penyediaan barang atau jasa untuk direntalkan kepada pihak lain, atau untuk tujuan administratif, dan diharapkan untuk digunakan selama lebih dari satu periode. Aset tetap pada PDAM Kabupaten Kudus diakui pada saat aset tetap siap untuk digunakan sebesar harga perolehannya yaitu harga beli ditambah dengan biaya - biaya yang dikeluarkan sampai aset tetap siap digunakan.

Penyusutan aset tetap PDAM Kabupaten Kudus dihitung mengikuti tarif perpajakan sesuai dengan UU No. 36 Tahun 2008 tentang pajak penghasilan. Dasar penyusunan pengelompokan aset tetap pada PDAM Kabupaten Kudus yaitu Peraturan Menteri Keuangan PMK. No.96/PMK.03/2009 tentang jenis-jenis harta yang termasuk dalam kelompok harta berwujud untuk keperluan penyusutan. PDAM Kabupaten Kudus telah melakukan pengelompokan aset tetapnya namun terdapat beberapa aset yang belum sesuai dalam pengelompokannya sehingga menyebabkan perbedaan tarif penyusutan.

Aset tetap dicatat ke dalam jurnal yang selanjutnya diposting ke dalam buku besar dan buku besar pembantu. PDAM Kabupaten Kudus hanya mencatat aset tetapnya ke dalam daftar aset tetap. PDAM Kabupaten Kudus belum melakukan pencatatan aset tetapnya ke dalam jurnal, buku besar, dan buku besar pembantu.

Aset tetap pada PDAM Kabupaten Kudus diungkapkan pada Laporan Posisi Keuangan dan Laporan Laba-Rugi. Pengungkapan dalam Laporan Posisi Keuangan yaitu sebesar harga perolehan dikurangi dengan akumulasi penyusutan yang menghasilkan nilai buku aset tetap. Pengungkapan dalam Laporan Laba-Rugi yaitu sebesar beban penyusutan pada pos biaya tidak langsung.

Perlakuan akuntansi aset tetap mulai dari pengakuan, pencatatan, sampai penyajian dalam Laporan Keuangan harus dinilai secara benar agar informasi aset tetap yang terdapat pada Laporan Keuangan sesuai dengan standar akuntansi yang berlaku. Berdasarkan latar belakang masalah tersebut, maka Tugas Akhir ini berjudul "perlakuan akuntansi aset tetap pada Perusahaan Daerah Air Minum Kabupaten Kudus".

\section{Tujuan Penulisan}

Tujuan penulisan Tugas Akhir ini adalah Untuk menghitung dan mengakui aset tetap pada PDAM Kabupaten Kudus. Untuk mencatat aset tetap pada PDAM Kabupaten Kudus. Untuk menyajikan dan mengungkapkan aset tetap pada PDAM Kabupaten Kudus ke dalam Laporan Keuangan.

\section{Tinjauan Pustaka}

Pengertian Aset Tetap

Ikatan Akuntan Indonesia menyatakan dalam PSAK No 16 Tahun 2015 aset tetap adalah aset berwujud yang dimiliki untuk digunakan dalam produksi atau penyediaan barang atau jasa untuk direntalkan kepada pihak lain, atau untuk tujuan administratif dan diharapkan untuk digunakan selama lebih dari satu periode.

\section{Klasifikasi Aset Tetap}

Berdasarkan Peraturan Menteri Keuangan Nomor 96/PMK.03/2009 tentang jenis-jenis harta yang termasuk dalam kelompok harta berwujud bukan bangunan untuk keperluan penyusutan. Aset tetap diklasifikasikan menjadi empat kelompok. 


\section{Pengakuan Aset Tetap}

Entitas harus mengakui aset tetap yang dimiliki apabila aset telah memenuhi pengertian dan memiliki sifat - sifat sebagaimana yang dimiliki aset tetap. Menurut Martani dkk (2012:272) sebagaimana pengakuan untuk aset lainnya, biaya perolehan aset tetap harus diakui sebagai aset jika dan hanya jika:

a. Besar kemungkinan manfaat ekonomis di masa depan berkenaan dengan aset tersebut akan mengalir ke entitas; dan

b. Biaya perolehan aset dapat diukur secara andal.

\section{Pengukuran Saat Pengakuan}

Berdasarkan IAI dalam PSAK No

16 Tahun 2015 Suatu aset tetap yang memenuhi kualifikasi pengakuan sebagai aset diukur pada biaya perolehan.

Biaya perolehan aset tetap meliputi:

a. Harga perolehannya, termasuk bea impor dan pajak pembelian yang tidak dapat dikreditkan setelah dikurangi diskon potongan lain.

b. Setiap biaya yang dapat diatribusikan secara langsung untuk membawa aset ke lokasi dan kondisi yang diinginkan supaya aset tersebut siap digunakan sesuai dengan intensi manajemen.

c. Estimasi awal biaya pembongkaran dan pemindahan aset tetap dan restorasi lokasi aset, kewajiban tersebut timbul ketika aset tersebut diperoleh atau sebagai konsekuensi penggunaan aset tetap selama periode tertentu untuk tujuan selain untuk memproduksi persediaan selama periode tersebut.

Contoh biaya yang dapat diatribusikan secara langsung adalah:

a. Biaya imbalan kerja (seperti didefinisikan dalam PSAK 24: Imbalan Kerja) yang timbul secara langsung dari pembangunan atau akuisisi aset tetap;

b. Biaya penyiapan lahan untuk pabrik;

c. Biaya penanganan dan penyerahan awal;

d. Biaya instalasi dan perakitan;

e. Biaya pengujian aset apakah aset berfungsi dengan baik, setelah dikurangi hasil neto penjualan setiap produkyang dihasilkan sehubungan dengan pengujian tersebut (seperti contoh produk yang dihasilkan dari peralatan yang sedang diuji); dan

f. Fee profesional.

Pengukuran Setelah Pengakuan Awal

Entitas harus melakukan pengukuran setelah pengakuan awal, entitas dapat memilih menggunakan model biaya atau model revaluasi sebagai kebijakan akuntansinya dan menerapkan kebijakan tersebut terhadap seluruh aset tetap dalam kelompok yang sama.

a. Model Biaya

Menurut Martani dkk (2012: 279)

dalam model biaya, setelah diakui sebagai aset maka suatu aset tetap dicatat sebesar biaya perolehan dikurangi akumulasi penyusutan dan akumulasi rugi penurunan nilai aset.

Penyusutan Aset Tetap

Menurut Martani dkk (2012:312)

Penyusutan adalah metode pengalokasian biaya aset tetap untuk menyusutkan nilai aset secara sistematis selama periode manfaat dari aset tersebut. Terdapat tiga hal yang harus dipertimbangkan suatu entitas dalam mengalokasikan nilai aset tetap sebagai biaya depresiasi, yaitu :

$\begin{array}{llll}\text { a. Nilai biaya } & \text { aset } & \text { yang } \\ \text { didepresiasikan } & & \\ \text { Nilai biaya } & \text { aset } & \text { yang }\end{array}$ didepresiasikan (depreciable asset ) merupakan nilai yang akan dialokasikan secara sistematis sepanjang masa manfaat dari aset. Nilai ini dihitung dengan mengurangkan biaya perolehan dari suatu aset (nilai pada saat pengukuran awal) terhadap estimasi nilai residu atau nilai sisa dari aset pada akhir periode masa manfaat aset tersebut. Nilai residu atau nilai sisa merupakan estimasi nilai yang akan diperoleh entitas ketika dilakukan penjualan aset atau penghentian aset dari penggunaannya ketika akhir periode masa manfaat aset.

b. Taksiran masa manfaat aset tetap Masa manfaat suatu aset merupakan jangka waktu dimana suatu aset diekspektasikan dapat digunakan 
oleh suatu entitas. Dalam menentukan masa manfaat suatu aset entitas mendasarkan pada kebijakan pengelolaan aset entitas yang didasarkan pada pertimbangan akan dilakukannya penghentian penggunaan suatu aset setelah waktu penggunaan tertentu atau pengonsumsian proporsi tertentu dari masa ekonomisnya. Selain itu, entitas juga seringkali menetapkan masa manfaat aset tetap berdasarkan pengelompokan aset yang disesuaikan dengan perlakuan yang berlaku seperti peraturan perpajakan dan lain-lain. Hal ini menyebabkan adanya perbedaan antara masa ekonomis aset dengan masa manfaat aset.

\section{c. Metode depresiasi yang sesuai}

Metode depresiasi menentukan cara dalam mengalokasikan penyusutan nilai aset secara sistematis selama periode masa manfaat aset. Metode yang dipilih oleh suatu entitas harus mencerminkan ekspektasi pola penggunaan aset. Pola penggunaan suatu aset dapat merupakan fungsi dari waktu atau fungsi dari penggunaan secara fisik. Berikut merupakan beberapa metode penyusutan aset tetap :

\section{1) Metode Garis Lurus}

Merupakan metode yang paling sederhana mengasumsikan adanya penggunaan yang konstan dari suatu aset selama masa manfaatnya. Metode ini merupakan metode yang mendasarkan alokasi dari fungsi waktu penggunaan aset. Berdasarkan metode ini biaya depresiasi dihitung dengan mengalokasikan nilai aset yang didepresiasikan selama masa manfaat aset secara sama untuk setiap periodenya. Untuk menghitung biaya depresiasi digunakan rumusan sebagai berikut.

Biaya Depresiasi

$=$ (Biaya Perolehan Aset-Nilai Residu)

2) Metode Pembebanan menurun

Metode pembebanan menurun memberikan pembebanan biaya depresiasi yang lebih tinggi pada tahun-tahun awal dari umur aset dan pembebanan yang rendah pada tahun - tahun akhir. Logika dari metode ini bahwa penggunaan suatu aset akan lebih tinggi pada tahun - tahun awal karena pada tahun - tahun awal produktivitas aset akan lebih tinggi dari tahun tahun akhir dari aset. Dua metode yang sering kali digunakan entitas dalam pembebanan menurun adalah metode jumlah angka tahun (sum of the years' digits method) dan metode saldo menurun (declining balance method).

Metode jumlah angka tahun merupakan metode depresiasi yang dihasilkan dari penghapusbukuan yang bersifat menurun di mana biaya depresiasi tahunan ditentukan dengan mengalikan biaya depresiasi dengan fraksi tahun sebagai tarif pembebanan depresiasi. Tarif pembebanan depresiasi merupakan rasio dengan denominatornya adalah jumlah tahun penggunaan aset (misalnya aset dengan masa manfaat 5 tahun memiliki denominator $15(5+4+3+2+1)$ dan numeratornya adalah jumlah tahun sisa pada awal yang belum didepresiasikan (misal pencatatan beban depresiasi pada tahun ketiga maka numeratornya adalah 3). Fraksi pengali pada metode ini numerator tersebut akan menurun seiring waktu denominatornya tetap $(5 / 15,4 / 15,3 / 15,2 / 15,1 / 15)$. Untuk menghitung biaya depresiasi digunakan rumus sebagai berikut:

Biaya Depresiasi $=$ Fraksi Depresiasi x (Nilai Perolehan Aset - Nilai Residu)

Saldo menurun ganda
merupakan metode membebankan depresiasi dengan nilai yang tinggi pada awal periode dan secara gradual akan berkurang pada tahun-tahun saelanjutnya. Pada metode ini beban depresiasi merupakan perkalian nilai buku aset dengan tarif depresiasi merupakan perkalian niai buku aset dengan tarif depresiasi yang dinyatakan dengan persentase di 
mana besarnya persentase biasanya dua kali lipat dari persentase garis lurus (misalkan aset dengan umur lima tahun memiliki tarif $40 \%$, dua kali tarif garis lurus sebesar 1/5 atau 20\% ). Berbeda dengan metode sebelumnya, pada metode ini nilai yang didepresiasikan tidak dikurangkan dengan nilai residunya (nilai perolehan aset). Untuk menghitung biaya depresiasi digunakan rumusan sebagai berikut:

Biaya Depresiasi $=$ Nilai Buku Awal Tahun x Tarif Saldo Menurun Tarif Penyusutan Aset Tetap

Berdasarkan Undang-undang Nomor 36 Tahun 2008 tentang pajak penghasilan, untuk menghitung penyusutan, masa manfaat dan tarif penyusutan harta berwujud ditetapkan sebagai berikut:

Tarif Penyusutan Aset Tetap Berwujud

\begin{tabular}{|l|l|l|l|}
\hline $\begin{array}{c}\text { Kelompok } \begin{array}{c}\text { Harta } \\
\text { Berwujud }\end{array} \\
\text { Manfaat }\end{array}$ & \multicolumn{1}{|c|}{$\begin{array}{c}\text { Masa } \\
\text { Menyusutan }\end{array}$} \\
\cline { 3 - 4 } & & $\begin{array}{c}|c| \\
\text { Garis } \\
\text { Lurus }\end{array}$ & $\begin{array}{c}\text { Saldo } \\
\text { Menurun }\end{array}$ \\
\hline I. Bukan & & & \\
Bangunan & & & \\
Kelompok 1 1 & 4 tahun & $25 \%$ & $50 \%$ \\
Kelompok 2 & 8 tahun & $12,5 \%$ & $25 \%$ \\
Kelompok 3 & 16 tahun & $6,25 \%$ & $12,5 \%$ \\
Kelompok 4 & 20 tahun & $5 \%$ & $10 \%$ \\
II. Bangunan & & & \\
Permanen & 20 tahun & $5 \%$ & \\
Tidak & 10 tahun & $10 \%$ & \\
Permanen & & & \\
\hline
\end{tabular}

Sumber : Undang-undang No 36, 2008

\section{Penghentian Aset Tetap}

Menurut IAI dalam PSAK No 16 Tahun 2015 Jumlah tercatat aset tetap dihentikan pengakuannya pada saat:

a. Dilepas; atau

b. Ketika tidak terdapat lagi manfaat ekonomi masa depan yang diharapkan dari penggunaan atau pelepasannya.

Keuntungan atau kerugian yang timbul dari penghentian pengakuan aset tetap dimasukkan dalam Laba-Rugi pada saat aset tersebut dihentikan pengakuannya (kecuali PSAK 30: Sewa mengharuskan perlakuan yang berbeda dalam hal transaksi jual dan sewa-balik).
Keuntungan tidak boleh diklasifikasikan sebagai pendapatan.

\section{Pengungkapan Aset Tetap}

Menurut Martani dkk (2012:290) laporan keuangan mengungkapkan untuk setiap kelompok aset tetap, antara lain :

a. Dasar pengukuran yang digunakan dalam menentukan jumlah tercatat bruto;

b. Metode penyusutan yang digunakan;

c. Umur manfaat atau tarif penyusutan yang digunakan;

d. Jumlah tercatat bruto dan akumulasi penyusutan (dijumlahkan dengan akumulasi rugi penurunan nilai) pada awal dan akhir periode; dan

e. Rekonsiliasi jumlah tercatat pada awal dan akhir periode yang menunjukkan:

1) Penambahan;

2) Aset diklasifikasi sebagai tersedia untuk dijual atau termasuk dalam kelompok lepasan yang diklasifikasikan sebagai tersedia untuk dijual sesuai dengan paragraph 45 atau pelepasan lainnya;

3) Akuisisi melalui kombinasi bisnis;

4) Peningkatan atau penurunan akibat dari revaluasi sesuai paragraf 31, 39, dan 40 serta dari rugi penurunan nilai yang diakui atau dijurnal pembalik secara langsung dengan sesuai PSAKNo. 48;

5) Rugi penurunan nilai yang diakui dalam Laba-Rugi sesuai PSAK 48;

6) Rugi penurunan nilai yang dijurnal balik dalam Laba-Rugi sesuai PSAK 48; jika ada

7) Penyusutan;

8) Selisih nilai tukar neto yang timbul dalam penjabaran Laporan Keuangan dari mata uang fungsional menjadi mata uang pelaporan yang berbeda, termasuk penjabaran dari kegiatan usaha luar negeri menjadi mata uang pelaporan dari entitas pelapor; dan 
9) Perubahan lain.

\section{PEMBAHASAN}

Perhitungan dan Pengakuan Aset Tetap PDAM Kabupaten Kudus

Aset tetap pada PDAM Kabupaten Kudus diperoleh dari pembelian pemberian atau hibah dan membangun sendiri. PDAM Kabupaten Kudus mengakui aset tetap pada saat aset tetap siap untuk digunakan dan diungkapkan sebesar harga perolehannya.

Perhitungan Dan Pengakuan Aset Tetap Pada Saat Perolehan Aset Tetap

Saldo awal aset tetap per 1 Januari 2016 pada PDAM Kaupaten Kudus ditentukan dengan cara menghitung harga perolehan aset tetap dari tahun perolehannya sampai dengan 1 Januari 2016. Sedangkan saldo akhir aset tetap 31 Desember 2016 diperoleh dari menambahkan saldo awal 1 Januari 2016 dengan penambahan aset tetap selama Tahun 2016. Daftar penambahan aset tetap tahun 2016 yang dimiliki PDAM Kabupaten Kudus dapat dilihat pada table penambahan Aset Tetap 2016.
Perhitungan Dan Pengakuan Aset Tetap Pada Saat Penyusutan Aset Tetap

Penyusutan aset tetap pada PDAM Kabupaten Kudus menggunakan metode saldo menurun, yaitu tarif penyusutan dikali harga perolehan di kurangi akumulasi penyusutan, PDAM tidak menerapkan estimasi nilai sisa apabila aset tetap telahhabis umur ekonomisnya. Tarif penyustan yang digunakan PDAM Kabupaten Kudus berdasarkan UU No 36 Tahun 2008 tentang pajak penghasilan. . Terdapat perbedaan antara perhitungan penyusutan tahun 2016 PDAM Kabupaten Kudus dan perhitungan berdasarkan PSAK sebesar Rp 210.693.103 dikarenakan terdapat perbedaan dalam pengelompokan aset tetap sehingga berpengaruh terhadap tarif penyusutan yang digunakan. Selain itu ada beberapa aset tetap yang sudah habis umur ekonomisnya dan tidak dilakukan penilaian kembali namun PDAM Kabupaten Kudus masih memperhitungkan penyusutannya.

Tabel Penambahan Asset Tetap Tahun 2016

\begin{tabular}{|c|c|c|c|c|c|c|}
\hline \multirow[b]{2}{*}{ No } & \multirow[b]{2}{*}{ Nama Aset Tetap } & \multicolumn{2}{|c|}{ Barang } & \multirow{2}{*}{\begin{tabular}{|c|} 
Umur \\
Ekonomis
\end{tabular}} & \multicolumn{2}{|r|}{ Perolehan } \\
\hline & & Jumlah & Satuan & & Tanggal & Nilai \\
\hline 1 & Tanah dan Hak atas Tanah & 0 & Unit & - & 2016 & $\mathrm{RpO}$ \\
\hline \multirow[t]{5}{*}{2} & Instalasi Sumber Air & & & & & \\
\hline & Bangunan dan Perbaikan & 3 & Unit & 16 Tahun & 2016 & Rp295.309.000 \\
\hline & Reservoir & 1 & Unit & 16 Tahun & 2016 & Rp540.164.000 \\
\hline & Sumur & 6[ & Unit & 16 Tahun & 2016 & Rp2.584.288.000 \\
\hline & Sumur & 3 & Unit & 16 Tahun & 2016 & Rp175.117.610 \\
\hline \multirow[t]{5}{*}{3} & Instalasi Perpompaan & & & & & \\
\hline & Bangunan dan Perbaikan & o & Unit & 16 Tahun & 2016 & $\mathrm{RpO}$ \\
\hline & Pembangkit Tenaga Listrik & 3 & Unit & 16 Tahun & 2016 & Rp533.138.300 \\
\hline & Peralatan Pompa & 17 & Unit & 16 Tahun & 2016 & Rp1.439.997.720 \\
\hline & Pompa Lainnya & 3 & Unit & 16 Tahun & 2016 & Rp311.385.000 \\
\hline \multirow[t]{4}{*}{4} & Pengolahan Air & & & & & \\
\hline & Bangunan dan Perbaikan & 0 & Unit & 16 Tahun & 2016 & $\mathrm{RpO}$ \\
\hline & reservoir & $\mathrm{O}$ & Unit & 16 Tahun & 2016 & RpO \\
\hline & Instalasi Pengolahan & 3 & Unit & 16 Tahun & 2016 & Rp739.630.000 \\
\hline \multirow[t]{4}{*}{5} & Instalasi Transmisi dan Distribusi & & & & & \\
\hline & InventarisTersier & 11 & Unit & 16 Tahun & 2016 & Rp11.363.119.366 \\
\hline & Reservoir & o & Unit & 16 Tahun & 2016 & RpO \\
\hline & Pipa Dinas & 11 & Unit & 16 Tahun & 2016 & Rp4.344.778.643 \\
\hline 6 & \begin{tabular}{|l|} 
Bangunan \\
\end{tabular} & 7 & Unit & 20 Tahun & 2016 & Rp1.015.631.000 \\
\hline \multirow[t]{5}{*}{7} & Perlengkapan & & & & & \\
\hline & Alat-alat Laborat & o & Unit & 4 Tahun & 2016 & RpO \\
\hline & Alat-alat Bengkel & o & Unit & 4 Tahun & 2016 & Rp4.125.000 \\
\hline & Alat Perhubungan & o & Unit & 4 Tahun & 2016 & RpO \\
\hline & Rupa-Rupa Perlengkapan & 2 & Unit & 4 Tahun & 2016 & Rp137.020.950 \\
\hline \multirow[t]{4}{*}{8} & Kendaraan & & & & & \\
\hline & Sepeda Kayuh & 0 & Unit & 4 Tahun & 2016 & RpO \\
\hline & Kendaraan Roda 2 & \begin{tabular}{l|l}
0 & \\
\end{tabular} & Unit & 8 Tahun & 2016 & RpO \\
\hline & Kendaraan Roda 4 & \begin{tabular}{l|l} 
\\
\end{tabular} & Unit & 8 Tahun & 2016 & RpO \\
\hline \multirow[t]{5}{*}{9} & Inventaris Kantor & & & & & \\
\hline & Mebelair Kantor & 1 & Unit & 8 Tahun & 2016 & Rp5.400.000 \\
\hline & Mesin Kantor & 3 & Unit & 4 Tahun & 2016 & Rp31.218.299 \\
\hline & Rupa-rupa Peralatan Kantor & 3 & Unit & 4 Tahun & 2016 & Rp65.323.900 \\
\hline & Jumlah & 77 & Unit & & & Rp23.585.646.788 \\
\hline
\end{tabular}


Perhitungan Dan Pengakuan Aset Tetap Pada Saat penghentian Aset Tetap

Aset tetap pada PDAM Kabupaten Kudus akan dihentikan pengakuannya dari kelompok aset tetap apabila aset tetap tersebut sudah tidak bisa memberikan manfaat ekonomis atau rusak. Selama tahun 2016, tidak terdapat penghentian pengakuan terhadap aset tetap PDAM Kabupaten Kudus.

\section{Pencatatan Aset Tetap PDAM Kabupaten} Kudus

PDAM Kabupaten Kudus sudah melakukan pencatatan aset tetapnya ke dalam daftar aset tetap. Namun PDAM Kabupaten Kudus belum melakukan pencatatan ke dalam jurnal, buku besar, dan buku besar pembantu.

\section{Pencatatan Aset Tetap Pada Saat} Perolehan

a. Jurnal

Transaksi penambahan aset tetap pada PDAM Kabupaten Kudus selama tahun 2016 yang diperoleh dari pembelian secara tunai. Jurnal penambahan aset tatap selama tahun 2016 dapat dilihat pada sebagai berikut:

\begin{tabular}{|c|c|c|c|c|}
\hline Tangg: & Keterangan & Ref & Debet & Kredit \\
\hline \multicolumn{5}{|c|}{2016} \\
\hline \multirow[t]{3}{*}{ April } & Instalasi Sumber Air & & Rp3.594.878.610 & \\
\hline & Kas & & & Rp33594.878.61 \\
\hline & (Pembelian Instalasi Sumber Air) & & & \\
\hline \multirow[t]{3}{*}{ Januari } & Instalasi Perpompaan & & Rp2.284.521.020 & \\
\hline & Kas & & & $\begin{array}{ll}\text { Rp2.284.521.02 } \\
\end{array}$ \\
\hline & (Pembelian instalasi perpompaan) & & & \\
\hline \multirow[t]{2}{*}{ Desember } & Instalasi Pengolahan & & $\begin{array}{l}\mathrm{Rp} 739.630 .000 \\
\end{array}$ & \\
\hline & Kas & & & $\begin{array}{ll}\mathrm{Rp} 739.630 .00 \\
\end{array}$ \\
\hline \multirow[t]{3}{*}{ Januari } & Instalasi Transmisi Dan Distribusi & & Rp15.707.898.008 & \\
\hline & Kas & & & Rp15.707.898.00 \\
\hline & (Pembelian instalasi transmisi dan distribusi ) & & & \\
\hline \multirow[t]{3}{*}{\begin{tabular}{|l|l|} 
Januari \\
\end{tabular}} & 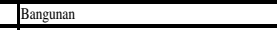 & & Rp1.051.631.000 & \\
\hline & Kas & & & Rp1.051.631.00 \\
\hline & (Pembelian Bangunan) & & & \\
\hline \multirow[t]{3}{*}{ Juli } & Peralatan dan Perlengkapan & & Rp141.145.950 & \\
\hline & Kas & & & $\begin{array}{ll}\text { Rp141.145.95 } \\
\end{array}$ \\
\hline & (Pembelian Peralatan dan perlengkapan) & & & \\
\hline \multirow[t]{5}{*}{ April } & Inventaris Kantor & & Rp101.941.200 & \\
\hline & Kas & & & Rp101.941.20 \\
\hline & \begin{tabular}{|l} 
(Pembelian Inventaris kantor) \\
\end{tabular} & & & \\
\hline & & & & \\
\hline & 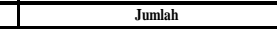 & & Rp23.585.645.788 & Rp235.85.645.78 \\
\hline
\end{tabular}

b. Buku Besar

Transaksi yang telah dicatat ke dalam jurnal, selanjutnya diposting ke buku besar masing-masing akun.

Pencatatan Aset Tetap Pada Saat Penyusutan

a. Jurnal

Jurnal penyusutan aset tetap pada PDAM Kabupaten Kudus selama tahun 2016 dapat dilihat pada tabel jurnal pada saat penyusutan.

b. Buku Besar
Transaksi yang telah dicatat ke dalam jurnal, selanjutnya diposting ke buku besar masing-masing akun.

c. Buku Besar Pembantu

Selain diposting kedalam buku besar asset tetap juga diposting ke dalam buku besar pembantu.

Tabel Jurnal Pada saat penyusutan

\begin{tabular}{|c|c|c|c|c|}
\hline \begin{tabular}{|l|l} 
Tanggal \\
\end{tabular} & Nama Akun dan Keterangan & Ref & Debit & 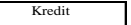 \\
\hline \multicolumn{5}{|c|}{2016} \\
\hline & ${ }^{31}$ Beban Penyusutan Instalasi sumber air & & Rp1.043.555.735 & \\
\hline & $\begin{array}{l}\text { Akumulasi Penyusutan Instalasi } \\
\text { sumber air }\end{array}$ & & & Rp1.043.555.735 \\
\hline & $\begin{array}{l}\text { (mencatat beban penyusutan instalasi } \\
\text { sumber air tahun 2016) }\end{array}$ & & & \\
\hline & $\begin{array}{ll}31 & \text { Beban Penyusutan instalasi perpompaan }\end{array}$ & & Rp1.742.476.187 & \\
\hline & $\begin{array}{l}\text { Akumulasi Penyusutan instalasi } \\
\text { perpompaan }\end{array}$ & & & Rp1.742.476.187 \\
\hline & $\begin{array}{l}\text { (mencatat beban penyusutan instalasi } \\
\text { perpompanan tahum } 2016 \text { ) }\end{array}$ & & & \\
\hline & 31 Beban Penyusutan instalasi pengolahan & & Rp184.817.404 & \\
\hline & $\begin{array}{l}\text { Akumulasi Penyusutan instalasi } \\
\text { pencolahan }\end{array}$ & & & Rp184.817.404 \\
\hline & (mencatat beban penyusutan instalasi & & & \\
\hline & $\begin{array}{l}\text { |pengolahan tatun 2016) } \\
\text { 31 Beban Penyusutan instalasi transmisi }\end{array}$ & & Rp6.762.294.843 & \\
\hline & $\begin{array}{l}\text { din distribusi } \\
\text { dat }\end{array}$ & & & \\
\hline & $\begin{array}{l}\text { Akumulasis Penyusutatan instalasi } \\
\text { transmisi dan distribusi }\end{array}$ & & & Rp6.762.294.843 \\
\hline & $\begin{array}{l}\text { mencatat beban penyusutan instalasi } \\
\text { transmisidan }\end{array}$ & & & \\
\hline & 31 Beban Penyusutan Bangunan & & Rp103.637.542 & \\
\hline & Akumulasi Penyusutan Bangunan & & & Rp103.637.542 \\
\hline & $\begin{array}{l}\text { (mencatat beban penyusutan Bangunan } \\
\text { tahen 2016) }\end{array}$ & & & \\
\hline & $\begin{array}{l}\text { 31 thahum 2016) } \\
31 \text { Beban Penyutan Peralatan dan } \\
\text { perleng kapanan }\end{array}$ & & Rp49.563.359 & \\
\hline & $\begin{array}{l}\text { Akumulasi Penyusutan Peralatan } \\
\text { dan perlengkapanan }\end{array}$ & & & R 49563359 \\
\hline & $\begin{array}{l}\text { mencatat beban penyusutan Peralatan } \\
\text { dan perlengkapan tahun } 2016 \text { (a) }\end{array}$ & & & \\
\hline & 31 Beban Penyusutan Kendaraan & & \begin{tabular}{l|l} 
Rp194.367.033 \\
\end{tabular} & \\
\hline & Akumulasi Penyusutan Kendaraan & & & \\
\hline & & & & Rp194.367.033 \\
\hline & $\begin{array}{l}\text { (mencatat beban penyusutan Kendaraan } \\
\text { tahun } 2016 \text {. }\end{array}$ & & & \\
\hline & 31 Beban Penysutan Inventaris kantor & & Rp133.438.063 & \\
\hline & $\begin{array}{l}\text { Akumulasi Penyusutan Inventaris } \\
\text { kantor }\end{array}$ & & & Rp133.438.063 \\
\hline & 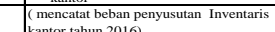 & & & \\
\hline & & & & \\
\hline & Jumlah & & Rp10.214.150.165 & Rp10.214.150.165 \\
\hline
\end{tabular}

Pencatatan Aset Tetap Pada Saat Penghentian

Penghentian aset tetap pada PDAM Kabupaten Kudus dicatat pada daftar aset tetap sebelah kredit sebesar aset tetap yang dihentikan. PDAM Kabupaten Kudus belum melakukan pencatatan penghentian aset tetap ke dalam jurnal dan buku besar. Selama tahun 2016 aset tetap pada PDAM Kabupaten Kudus tidak terdapat penghentian aset tetap sehingga tidak terdapat jurnal maupun buku besar.

Pengungkapan dan Penyajian Aset Tetap PDAM Kabupaten Kudus pada Laporan Keuangan

Aset tetap PDAM Kabupaten Kudus disajikan dan diungkapkan dalam Laporan Posisi Keuangan dan Laporan Laba-Rugi. Pengungkapan dalam Laporan Posisi Keuangan yaitu sebesar harga perolehan dikurangi dengan akumulasi penyusutan yang menghasilkan nilai buku aset tetap. Pengungkapan dalam Laporan Laba-Rugi 
yaitu sebesar beban penyusutan pada pos biaya tidak langsung.

Pengungkapan dan Penyajian Aset Tetap dan Akumulasi Aset Tetap Pada Laporan Posisi Keuangan

Aset tetap diungkapkan ke dalam Laporan Posisi Keuangan sebesar nilai bukunya yaitu aset tetap di kurang akumulasi penyusutan aset tetap. Penyajian aset tetap pada Laporan Posisi Keuangan dapat dilihat pada tabel sebagai berikut

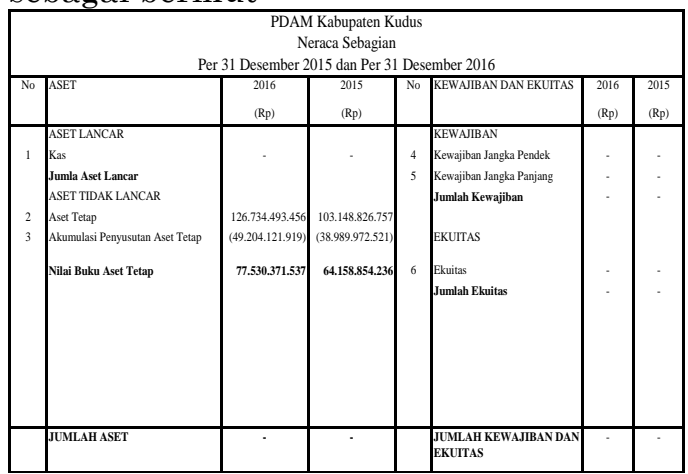

Pengungkapan dan Penyajian Beban Penyusutan Aset Tetap Pada Laporan Laba-Rugi

Pengungkapan dalam Laporan Laba-Rugi yaitu sebesar beban penyusutan pada pos biaya tidak langsung usaha. Pengungkapan beban penyusutan dapat dilihat pada table sebagai berikut:

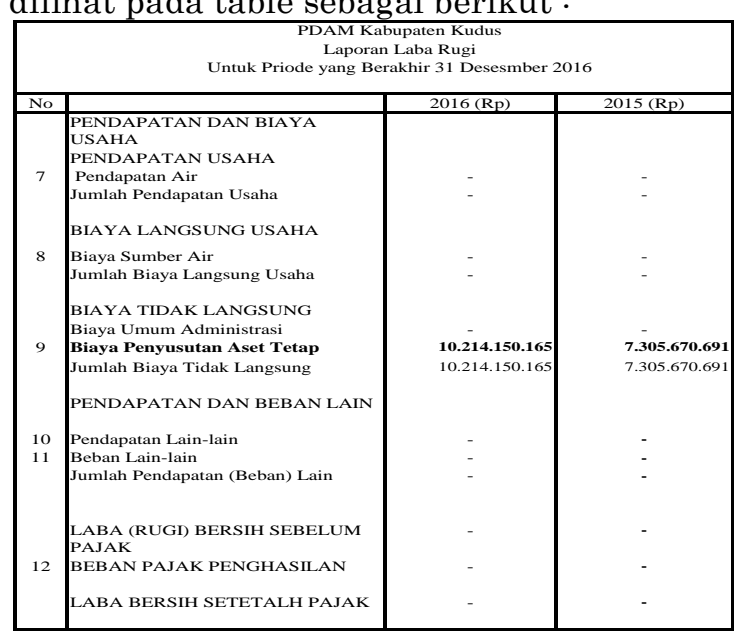

Penyajian dan Pengungkapan Aset Tetap pada Catatan atas Laporan Keuangan

Aset tetap dinyatakan sebesar harga perolehannya, yaitu harga beli ditambah dengan biaya yang dikeluarkan untuk memperoleh aset tersebut sampai dapat dimanfaatkan. Aset tetap dikelompokkan sesuai dengan Peraturan Menteri
Keuangan PMK No 96/PMK.03/2009 tetntang jenis-jenis harta yang termasuk dalam kelompok harta berwujud untuk keperluan penyusutan. Penyusutan aset tetap dihitung dengan menggunakan saldo menurun dan tarif penyusutan berdasarkan UU No 36 Tahun 2008 tentang pajak penghasilan. Tidak terdapat nilai residu pada saat aset tetap habis umur ekonomisnya.

\section{Kesimpulan}

Berdasarkan tujuan Tugas Akhir, dapat diambil kesimpulan sebagai berikut :

Asset tetap pada PDAM Kabupaten Kudus diakui pada saat aset tetap diperoleh dan siap untuk digunakan. Perhitungan harga perolehan aset tetap sampai dengan 31 Desember 2016 yaitu sebesar Rp 126.734.493.456, perhitungan akumulasi penyusutan aset tetap sampai dengan 31 Desember 2016 yaitu sebesar Rp 49.204.121.919 dan beban penyusutan tahun 2016 yaitu sebesar $R p$ 10.214.150.165 sehingga diperoleh nilai buku 31 Desember 2016 sebesar Rp 77.530.371.537.

PDAM Kabupaten Kudus telah mencatat aset tetapnya pada daftar aset tetap. Aset tetap PDAM Kabupaten Kudus belum dicatat ke dalam jurnal, buku besar, dan buku besar pembantu. Pencatatan ke dalam jurnal meliputi jurnal perolehan aset tetap dan jurnal penyusutan aset tetap. Pencatatan ke dalam buku besar meliputi buku besar aset tetap dan buku besar akumulasi penyusutan aset tetap.

Harga perolehan aset tetap dan akumulasi penyusutan aset tetap diungkapkan dalam Neraca per 31 Desember 2015 dan Neraca per 31 Desember 2016 sebesar nilai buku. Beban penyusutan aset tetap diungkapkan pada Laporan Laba-rugi untuk periode yang berakhir 31 Desember 2016 dalam pos biaya tidak langsung. 


\begin{tabular}{|c|c|c|c|}
\hline $\begin{array}{l}\mathrm{N} \\
\mathrm{o}\end{array}$ & $\begin{array}{l}\text { Menurut } \\
\text { PSAK }\end{array}$ & $\begin{array}{l}\text { Menurut } \\
\text { PDAM } \\
\text { Kabupaten } \\
\text { Kudus }\end{array}$ & Evaluasi \\
\hline 1 & $\begin{array}{l}\text { Klasifikasi } \\
\text { Aset Tetap } \\
\text { Berdasarkan } \\
\text { Peraturan } \\
\text { Menteri } \\
\text { Keuangan } \\
\text { Nomor } \\
\text { 96/PMK.03/2 } \\
\text { 009 tentang } \\
\text { jenis-jenis } \\
\text { harta yang } \\
\text { termasuk } \\
\text { dalam } \\
\text { kelompok } \\
\text { harta } \\
\text { berwujud } \\
\text { bukan } \\
\text { bangunan } \\
\text { untuk } \\
\text { keperluan } \\
\text { penyusutan. } \\
\text { Aset tetap } \\
\text { diklasifikasi } \\
\text { kan menjadi } \\
\text { empat. }\end{array}$ & $\begin{array}{l}\text { Aset Tetap } \\
\text { PDAM di } \\
\text { klasifikasik } \\
\text { an } \\
\text { berdasarka } \\
\text { n Peraturan } \\
\text { Menteri } \\
\text { Keuangan } \\
\text { Nomor } \\
\text { 96/PMK.03/ } \\
\text { 2009 } \\
\text { tentang } \\
\text { jenis-jenis } \\
\text { harta yang } \\
\text { termasuk } \\
\text { dalam } \\
\text { kelompok } \\
\text { harta } \\
\text { berwujud } \\
\text { bukan } \\
\text { bangunan } \\
\text { untuk } \\
\text { keperluan } \\
\text { penyusutan }\end{array}$ & $\begin{array}{l}\text { Aset } \\
\text { tetap } \\
\text { kendaraa } \\
\text { n roda } \\
\text { dua pada } \\
\text { PDAM } \\
\text { Kudus } \\
\text { masuk } \\
\text { dalam } \\
\text { kelompok } \\
\text { II yang } \\
\text { seharusn } \\
\text { ya } \\
\text { masuk } \\
\text { dalam } \\
\text { kelompok } \\
\text { I. }\end{array}$ \\
\hline 2 & $\begin{array}{l}\text { Pengakuan } \\
\text { Aset Tetap } \\
\text { Entitas } \\
\text { harus } \\
\text { mengakui } \\
\text { aset tetap } \\
\text { yang } \\
\text { dimiliki } \\
\text { apabila aset } \\
\text { telah } \\
\text { memenuhi } \\
\text { pengertian } \\
\text { dan } \\
\text { memiliki } \\
\text { sifat - sifat } \\
\text { sebagaiman } \\
\text { a yang } \\
\text { dimiliki } \\
\text { aset tetap. } \\
\text { biaya } \\
\text { perolehan } \\
\text { aset tetap } \\
\text { harus } \\
\text { diakui } \\
\text { sebagai aset }\end{array}$ & $\begin{array}{l}\text { Aset tetap } \\
\text { di PDAM } \\
\text { Kabupaten } \\
\text { Kudus } \\
\text { diakui } \\
\text { berdasarka } \\
\text { n harga } \\
\text { perolehann } \\
\text { ya. Tanah } \\
\text { dan } \\
\text { bangunan } \\
\text { dicatat } \\
\text { secara } \\
\text { terpisah } \\
\text { sesuai } \\
\text { dengan } \\
\text { kelompok } \\
\text { masing- } \\
\text { masing } \\
\text { asset. }\end{array}$ & $\begin{array}{l}\text { Sudah } \\
\text { Sesuai }\end{array}$ \\
\hline
\end{tabular}

\begin{tabular}{|c|c|c|c|}
\hline & $\begin{array}{l}\text { jika dan } \\
\text { hanya jika: } \\
\text { Besar } \\
\text { kemungkin } \\
\text { an manfaat } \\
\text { ekonomis di } \\
\text { masa depan } \\
\text { berkenaan } \\
\text { dengan aset } \\
\text { tersebut } \\
\text { akan } \\
\text { mengalir ke } \\
\text { entitas; dan } \\
\text { Biaya } \\
\text { perolehan } \\
\text { aset dapat } \\
\text { diukur } \\
\text { secara } \\
\text { andal. }\end{array}$ & & \\
\hline 3 & $\begin{array}{l}\text { Pengukuran } \\
\text { Saat } \\
\text { Pengakuan } \\
\text { Berdasarkan } \\
\text { IAI dalam } \\
\text { PSAK No } 16 \\
\text { Tahun } 2015 \\
\text { Suatu aset } \\
\text { tetap yang } \\
\text { memenuhi } \\
\text { kualifikasi } \\
\text { pengakuan } \\
\text { sebagai aset } \\
\text { diukur pada } \\
\text { biaya } \\
\text { perolehan. }\end{array}$ & $\begin{array}{l}\text { PDAM } \\
\text { Kabupaten } \\
\text { Kudus } \\
\text { mempertim } \\
\text { bangkan } \\
\text { biaya-biaya } \\
\text { dikeluarkan } \\
\text { pada saat } \\
\text { pengakuan } \\
\text { asset tetap. }\end{array}$ & $\begin{array}{l}\text { Sudah } \\
\text { sesuai }\end{array}$ \\
\hline 4 & $\begin{array}{l}\text { Pengukuran } \\
\text { Setelah } \\
\text { Pengakuan } \\
\text { Awal } \\
\text { Entitas } \\
\text { harus } \\
\text { melakukan } \\
\text { pengukuran } \\
\text { setelah } \\
\text { pengakuan } \\
\text { awal, entitas } \\
\text { dapat } \\
\text { memilih } \\
\text { menggunaka } \\
\text { n model } \\
\text { biaya atau } \\
\text { model } \\
\text { revaluasi } \\
\text { sebagai } \\
\text { kebijakan }\end{array}$ & $\begin{array}{l}\text { Nilai buku } \\
\text { asset tetap } \\
\text { PDAM } \\
\text { Kabupaten } \\
\text { Kudus } \\
\text { ditentukan } \\
\text { dengan cara } \\
\text { mengurang } \\
\text { kan harga } \\
\text { perolehan } \\
\text { dengan } \\
\text { akumulasi } \\
\text { penyusutan } \\
\text {. }\end{array}$ & $\begin{array}{l}\text { Sudah } \\
\text { sesuai }\end{array}$ \\
\hline
\end{tabular}




\begin{tabular}{|c|c|c|c|}
\hline & $\begin{array}{l}\text { akuntansi } \\
\text { dan } \\
\text { menerapkan } \\
\text { kebijakan } \\
\text { tersebut } \\
\text { terhadap } \\
\text { seluruh aset } \\
\text { tetap dalam } \\
\text { kelompok } \\
\text { yang sama. }\end{array}$ & & \\
\hline 5 & $\begin{array}{l}\text { Penyusutan } \\
\text { Aset Tetap } \\
\text { Penyusutan } \\
\text { adalah } \\
\text { metode } \\
\text { pengalokasia } \\
\mathrm{n} \text { biaya aset } \\
\text { tetap untuk } \\
\text { menyusutka } \\
\mathrm{n} \text { nilai aset } \\
\text { secara } \\
\text { sistematis } \\
\text { selama } \\
\text { periode } \\
\text { manfaat dari } \\
\text { aset tersebut }\end{array}$ & $\begin{array}{l}\text { PDAM } \\
\text { Kabupaten } \\
\text { Kudus } \\
\text { menggunak } \\
\text { an metode } \\
\text { penyusutan } \\
\text { saldo } \\
\text { menurun } \\
\text { tanpa nilai } \\
\text { sisa dengan } \\
\text { tarif } \\
\text { penyusutan } \\
\text { berdasarka } \\
\text { n UU No } 36 \\
\text { tahun } 2008 \\
\text { tentang } \\
\text { pajak } \\
\text { penghasilan }\end{array}$ & $\begin{array}{l}\text { Terdapat } \\
\text { perbedaa } \\
\mathrm{n} \\
\text { penyusut } \\
\text { an } \\
\text { dikarena } \\
\text { kan } \\
\text { perbedaa } \\
\mathrm{n} \text { dalam } \\
\text { mengelo } \\
\text { mpokkan } \\
\text { asset } \\
\text { tetap dan } \\
\text { terdapat } \\
\text { beberapa } \\
\text { asset } \\
\text { tetap } \\
\text { yang } \\
\text { habis } \\
\text { umur } \\
\text { ekonomis } \\
\text { nya } \\
\text { namun } \\
\text { tetap } \\
\text { disusutk } \\
\text { an }\end{array}$ \\
\hline 6 & $\begin{array}{l}\text { Penghentian } \\
\text { Aset Tetap } \\
\text { Menurut IAI } \\
\text { dalam PSAK } \\
\text { No } 16 \text { Tahun } \\
2015 \text { Jumlah } \\
\text { tercatat aset } \\
\text { tetap } \\
\text { dihentikan } \\
\text { pengakuann } \\
\text { ya pada } \\
\text { saat: } \\
\text { Dilepas; } \\
\text { atau } \\
\text { Ketika tidak } \\
\text { terdapat lagi } \\
\text { manfaat } \\
\text { ekonomi } \\
\text { masa depan }\end{array}$ & $\begin{array}{l}\text { Selama } \\
\text { tahun } 2016 \\
\text { tidak } \\
\text { terdapat } \\
\text { penghentia } \\
\text { n asset } \\
\text { tetap pada } \\
\text { PDAM } \\
\text { Kabupaten } \\
\text { Kudus }\end{array}$ & $\begin{array}{l}\text { Sudah } \\
\text { sesuai }\end{array}$ \\
\hline
\end{tabular}

\begin{tabular}{|c|c|c|c|}
\hline & $\begin{array}{l}\text { yang } \\
\text { diharapkan } \\
\text { dari } \\
\text { penggunaan } \\
\text { atau } \\
\text { pelepasanny } \\
\text { a. }\end{array}$ & & \\
\hline 7 & $\begin{array}{l}\text { Pengungkap } \\
\text { an } \\
\text { Setiap } \\
\text { perusahaan } \\
\text { diharuskan } \\
\text { mengungkap } \\
\text { kan asset } \\
\text { tetap ke } \\
\text { dalam } \\
\text { Laporan } \\
\text { Keuangan. }\end{array}$ & $\begin{array}{l}\text { Aset tetap } \\
\text { PDAM } \\
\text { Kabupaten } \\
\text { Kudus } \\
\text { diungkapka } \\
\text { n ke dalam } \\
\text { Laporan } \\
\text { Posisi } \\
\text { Keuangan } \\
\text { sebesar } \\
\text { nilai buku. } \\
\text { Dan } \\
\text { mengungka } \\
\text { pkan beban } \\
\text { penyusutan } \\
\text { ke dalam } \\
\text { Laporan } \\
\text { Laba Rugi } \\
\text { pada pos } \\
\text { biaya tidak } \\
\text { langsung. }\end{array}$ & $\begin{array}{l}\text { Sudah } \\
\text { sesuai }\end{array}$ \\
\hline
\end{tabular}

DAFTAR PUSTAKA

Alek dan Achmad. 2011. Bahasa Indonesia Untuk PerguruanTinggi. Jakarta: Kencana.

Bungin, M Burhan. 2013. Metodologi Penelitian Sosial dan Ekonomi. Jakarta: Kencana Prenada Media Group.

Ikatan Akuntan Indonesia. 2015. Standar Akuntansi Keuangan. Jakarta: Ikatan Akuntan Indonesia.

Martani Dwi dkk. 2012. Akuntansi Keuangan Menengah Berbasis PSAK. Buku 1. Jakarta Selatan: Salemba Empat.

Marzuki. 2005. Metodologi Riset. Yogyakarta: Ekonisia.

Peraturan Menteri Keuangan Nomor 96/PMK.03/2009 Tentang JenisJenis Harta Yang Termasuk Dalam Kelompok Harta Berwujud Untuk Keperluan Penyusutan. 
Sujarweni V. Wiratna. Metodologi Penelitian-Bisnis \& Ekonomi. Yogyakarta: Pustaka Baru Press. Undang-undang Nomor 36 Tahun 2008 tentang pajak penghasilan. 